\title{
7
}

\section{Does a Responsible University Need a Third Mission?}

\author{
James Karlsen and Miren Larrea
}

\section{Introduction}

Over the last two decades, the discourse on the role of universities and higher education institutions in innovation, economic growth, social change and regional development has expanded. Universities have been urged to become more socially accountable and to contribute directly to local, regional and national economic development (e.g. Dunning 2002; Laredo 2007; OECD 2009). Various models of the socially responsible university have been developed, such as the entrepreneurial university (Clark 1998, 2004), the Mode 2 university (Nowotny et al. 2001), the triple helix model (Etzkowitz and Leydesdorff 1995), the engaged university (Boyer 1990) and the civic university (Goddard et al. 2016). For

\footnotetext{
J. Karlsen $(\bowtie)$

University of Agder, Grimstad, Norway

e-mail: james.karlsen@uia.no

M. Larrea
}

Orkestra-Basque Institute of Competitiveness, University of Deusto, San Sebastian, Spain

e-mail: miren.larrea@orkestra.deusto.es 
the sake of the argument about the regional role of the university, we distinguish between two university models, the add-on model and the integrated model, and we begin with the former model. It has been argued that regional development represents a new third mission for universities, in addition to the first (teaching) and the second (research) missions (Perkmann et al. 2013). The third mission is a general concept that covers all kind of university activities outside academic environments (Molas-Gallart and Castro-Martínez 2007). It is an add-on to the traditional activities of universities and is organised separately from the first two missions. The concept of the entrepreneurial university (Clark 1998; Etzkowitz 1983) focuses on the addition of a range of knowledge transfer and market-oriented activities, such as the incubation of start-up firms, the commercialisation of knowledge, the development of knowledge transfer partnerships and the delivery of entrepreneurship courses.

The university models that employ the integrated approach include the Mode 2 university (Nowotny et al. 2001) and the civic university (Goddard 2009; Goddard et al. 2016). The authors of these models argue that the third mission should be integrated into all university activities and practices, that is, into the first and second missions. They claim that this would engage the entire university as a knowledge institution in social and regional development. The authors of the Mode 2 university model argue that the mode of knowledge production in society has changed and that the university must adapt to this new mode of knowledge production (Mode 2) to survive.

The aforementioned models present challenges for universities. Rothaermel et al. (2007) argue that the entrepreneurial university represents the next logical step of the development of the university. Goddard (2011) claims that universities must be more rigorously managed to meet strategic priorities regarding entrepreneurship and knowledge-based development. Pinheiro et al. (2012b) argue that such an approach assumes that a university is an organisation that can orientate teaching and research resources towards regional development processes. However, if the university is not such an organisation, that is, an organisation that cannot be managed rigorously, how can it then integrate the third mission (regional development) into the two other missions? Moreover, what kind of organisation is the university? 
This chapter aims to contribute to the literature on universities' role in regional development. First, in the theoretical section, we address the question of what kind of organisation a university is. We distinguish between the university as a homogeneous (tightly coupled) organisation and as a heterogeneous (loosely coupled) organisation. Second, we connect the concept of regional development to a responsible research and innovation approach. The main topic of the book is the Responsible University and our argument is that universities should take a responsible approach to regional development. Our approach to responsibility departs from the theory of responsible research and innovation (Stilgoe et al. 2013) and especially the dimension of care (Bardone and Lind 2016; Wilford 2015). The responsible research and innovation approach does not distinguish the institutional from the personal and requires that individuals take personal responsibility for their own actions while also reinforcing institutional responsibility for setting policy and providing redress (Wilford 2018, 541). Responsibility concerns how researchers practice their work and relate to external actors. It describes a type of active engagement in the world that entails researchers becoming part of their own practice. ${ }^{1}$ An example of responsibility is that we, the authors, write in the first person and that we are explicit about our engagement in the case we present and our aim for change. As researchers, we must choose whether we write about the university in a detached manner, as if we were not part of the university, or whether we act and write responsibly and, thus, take responsibility for the change process. In this chapter, we cast light on regional responsibility from the positions of different groups within universities, such as researchers, teachers, students and management.

Third, we respond to the lack of in-depth studies of universities engagement with regional actors conducted from the inside and out. It is time to open the black box of universities and study micro-engagement between university actors and external actors. We present an action research case between master students, their teachers and external actors in a university city over one semester. Action research is a methodology that involves working together with actors. It entails co-generating knowledge with actors through action and reflection cycles (Greenwood and Levin 2007). Action research can adopt a process approach or both a 
process and product approach. The former is usually referred to as reflection-in-action while the latter is reflection-on-action (Schön 1983). This chapter takes a process approach. The case presented is that of the University of Agder, Norway, which is a relatively young public university. The question we explore is: Does a responsible university need a third mission?

\section{Theoretical Framework}

In this chapter, we introduce two theoretical discussions that frame the case study and discussion. One examines whether universities are homogeneous or heterogeneous in nature, and the other addresses the interactions between the individual and organisational levels in third mission strategies. At the end of this section, we integrate them both into an analytical framework.

\section{The Homogeneous or Heterogeneous Nature of Universities}

We find the previous discourses on universities and their engagement with external actors challenging for a discussion at the micro level because they are abstract and use generic concepts. What kind of higher education are we talking about? The discourses on universities do not always distinguish between different types of universities. As Greenwood and Levin $(2016,22)$ argue:

There are community colleges, for-profit colleges and universities, vocational schools, liberal arts colleges, regional colleges, private universities, flagship public universities, land-grant universities, state university and colleges systems and national public university systems in Europe.

However, we not only have to consider differences between universities but also within universities. Greenwood and Levin (2016) describe the university as a collection of different systems that interact and consider 
administration, students and faculty as three different groups in these interactions.

The methodological problem is that by abstracting, homogenising and analysing universities, we treat them as the same type of university, and by interpreting the university as a homogeneous organisation without considering the complexity inside each university, we have a 'one-sizefits-all' university model. Moreover, we run the risk of making analytical errors, which also can have consequences for the future policies of universities if policy-makers use the analysis. As Greenwood and Levin (2016) demonstrate, universities differ and they are internally complex. Therefore, there is a need for more precision and for a nuanced debate on universities that considers questions such as what kind of universities we are talking about, how they are configured and the context in which are they located.

In recent years, scholarly discourse has begun to question the basic assumption that universities are organisations with homogeneous and uniform capacities to perform and contribute to social engagement (Kitagawa et al. 2016; Pinheiro et al. 2012a; Sánchez-Barrioluengo 2014). Empirical studies show that universities are extremely diverse and that they tend to respond differently to external opportunities and challenges. A comparative case study of universities in the United Kingdom, Austria and Sweden shows that policies in these different countries tend to favour different models of university third mission engagement (Trippl et al. 2015). Numerous studies have shown that universities are heterogeneous organisations in their third mission activities (Charles et al. 2014; Hewitt-Dundas 2012; Huggins et al. 2012; Kitagawa et al. 2016). It seems that each university develops its approach to the third mission by targeting different areas of activities (Kitagawa et al. 2016, 736). This paper contributes to this literature by following the path initiated by Greenwood and Levin (2016) and proposing action research as a research strategy that helps integrate the internal specificities of universities into the research process.

The central problem that this theoretical framework addresses is that, with exceptions such as those previously cited, most approaches seem to involve an implicit assumption that a one-size-fits-all model can be applied to universities and that a university is an organisation with 
homogeneous and uniform capacities to perform and contribute to social and regional engagement.

In this chapter, we propose an interpretation of university and regions as loosely coupled systems in which different actors interact from different positions and with different interests. In this context, regional engagement is the result of such interactions, which include learning and negotiation across groups. These activities of learning and negotiation sometimes happen inside the university between the different actors that form the university and sometimes between university actors and regional actors.

The idea that universities are heterogeneous and loosely coupled organisations is inspired by Weich (1976). This idea implies that the connections between the various internal subsystems may be infrequent, circumscribed, weak in mutual effects, unimportant or slow (Weich 1976). By contrast, a homogenous organisation is a tightly coupled organisation.

\section{Regional Responsibility}

It is with the previous discussion in mind that we approach the issue of responsibility, which is the thread that runs through the different chapters in this book. Our approach builds on the responsible research and innovation approach (Spruit et al. 2015; Stilgoe et al. 2013) and especially on the new dimension of care (Bardone and Lind 2016; Burget et al. 2017; Wilford 2015). Stilgoe et al. (2013, 1570) define responsible research and innovation as 'taking care of the future through collective stewardship of science and innovation in the present'. The dimension of care stresses the importance of personal responsibility (Wilford 2015) in addition to a collective approach to the research and innovation process. Care is a process through which people collaboratively develop abilities to perceive, act and judge (Burget et al. 2017; Groves 2009). Care is not a set of normative rules on how to act but rather the decisions and actions of an individual, such as a researcher, teacher or student. It is a 'way to bring together people's high objectives and day-to-day practices' (Burget et al. 2017, 13). 
Responsibility as care concerns the concrete behaviour of individuals and organisations and on how care is embodied in their daily activities. This means that, in this chapter, formal documents on university missions with regard to regional engagement and normative discourses are relevant but not central. The approach of responsibility as care is mainly observable in an individual's actions. It is a type of active engagement in the world, which means that researchers cannot be separated from their practice and are, therefore, embodied in practice. This brings researchers' agency to the forefront and contrasts with the vision of responsibility as a set of guidelines imposed externally to obtain funding or to engage in specific modes of behaviour with the broader society and regional actors to be a responsible university. Regional responsibility is about care for the region in which the university is located, both on the institutional (collective) level and the personal level and in the connections between these levels.

\section{An Analytical Model}

Based on the points discussed above, we have constructed an analytical framework (see Table 7.1). The first dimension in the model is the

Table 7.1 Regional responsibility in tightly and loosely coupled organisations

\begin{tabular}{|c|c|c|c|}
\hline & & \multicolumn{2}{|c|}{ View of regional responsibility as } \\
\hline & & Organisational rules & $\begin{array}{l}\text { Individual } \\
\text { practice }\end{array}$ \\
\hline \multirow[t]{2}{*}{$\begin{array}{l}\text { Interpretation } \\
\text { of the } \\
\text { university as } \\
\text { a }\end{array}$} & $\begin{array}{l}\text { Tightly coupled } \\
\text { organisation } \\
\text { (homogeneous) }\end{array}$ & $\begin{array}{l}\text { A set of codified } \\
\text { guidelines for } \\
\text { responsible } \\
\text { regional } \\
\text { development }\end{array}$ & $\begin{array}{l}\text { Following } \\
\text { established rules } \\
\text { for responsible } \\
\text { regional } \\
\text { development }\end{array}$ \\
\hline & $\begin{array}{l}\text { Loosely coupled } \\
\text { organisation } \\
\text { (heterogeneous) }\end{array}$ & $\begin{array}{l}\text { A set of norms and } \\
\text { values developed } \\
\text { by each unit for } \\
\text { regional } \\
\text { responsibility based } \\
\text { on individual and } \\
\text { shared experiences }\end{array}$ & $\begin{array}{l}\text { Space for } \\
\text { individual } \\
\text { responsibility } \\
\text { adapted to the } \\
\text { regional context }\end{array}$ \\
\hline
\end{tabular}


perception of the university as either a tightly coupled organisation (homogeneous) or a loosely coupled organisation. We use the term 'perception' because, although we have made clear in the previous sections that we build on literature that regards universities as heterogeneous entities, we also consider that some university processes are defined based on the assumption that universities are homogeneous entities and some processes are built on the assumption that universities are heterogeneous entities. The coexistence of these processes is one of the main challenges in the development of third mission strategies today, and we want the analytical framework to reflect that.

The second dimension is responsibility as either a set of codified organisational rules or individual responsible practice. In a university, there are different types of individuals, such as teachers, researchers and students, who engage in different practices. Management practices, such as those of the university director, managers at different levels in the university and project leaders, are also included in these individual practices with external actors. We interpret the university as a tightly coupled organisation when there is a set of codified rules for regional engagement. This does not necessarily imply a restricted space for individual practice and adaptation to the external context either within the university or with regional actors. $^{2}$ Generally, however, when the focus is on codified rules to guide individual action, little attention is given, and few resources are allocated, to such individual practices. With a strategy that conceives the university as a loosely coupled organisation, each unit, such as a department, develops a set of informal norms and values for engagement with regional actors, and individual practices are at the core of those norms and values. This also implies that there some units may have no, or almost no, engagement with regional actors, while other units may allow space for individual engagement with regional actors. Furthermore, in each unit, there might be highly engaged individuals and individuals with no engagement at all. In a loosely coupled organisation, there is space for individual practice and adaptation to the regional context. This space exists if individuals want to avail of it, but there is also space for not engaging with regional actors.

In proposing the aforementioned framework, we do not mean to suggest that there are only two models for universities' positions on regional 
responsibility. There are many nuanced models and they depend on the type of university. We want to discuss that how these two analytical types can be combined by adopting multiple approaches. We argue that third mission strategies often assume that universities are tightly coupled organisations and that such strategies can be difficult to implement if universities are not tightly coupled. At the same time, individuals or units within the university that feel responsible for the region may implement initiatives and engage with regional actors in their daily endeavours, and these initiatives and endeavours may not be considered part of the third mission strategy. We want to use our framework to argue that a responsible strategy for the third mission is one that considers both individual initiatives and codified guidelines as part of the third mission.

\section{Methodology}

Our methodological approach is based on action research. Action research is considered the most appropriate meta-methodology for exploring lived practical knowledge that informs a community of practice (Guba and Lincoln 2005). The case we present in this chapter was designed as an action research process. Action research is concerned with praxis, a concept that integrates practice and theory. It is a research strategy that integrates action, reflection and participation with various actors through a cyclic, dialogical process aimed at change (Greenwood and Levin 2007; Reason and Bradbury 2008), such as for territorial development (Karlsen and Larrea 2014, 2018). Action research is designed for working with change processes in real time and from both inside and outside the university since it involves cycles of reflection and action. It involves participation and engagement with regional actors, where the action researcher is considered both an insider and an equal regional actor with other regional actors, such as industry actors and policy-makers (Karlsen and Larrea 2014, 2018). When we refer to actors, we might refer to individuals (e.g. specific firm representatives, policy-makers, politicians, researchers) or the organisations they represent in their interactions (e.g. firms, governments, universities). 


\section{Context, Method and Data}

The data presented is from an action research process with university actors from the University of Agder and actors from Grimstad municipality, which is the host region of one of the University of Agder's two campuses in the Agder region in Norway. The Agder region is the most southern region in Norway and consists of the two counties, that is, AustAgder County and Vest-Agder County. It has 305,000 inhabitants, which is $5.8 \%$ of the population of Norway. The University of Agder is a public university with approximately 13,000 students and 1300 employees (2019). Grimstad has approximately 23,000 inhabitants, and there are around 3500 students on the Grimstad campus, mainly engineering and nursing students but also innovation students from the Department of Working Life and Innovation, which belongs to the School of Business and Law. The students and the staff from that department are the university actors in this case.

The case was conducted from early spring 2017 to the end of 2018. Collaborative activities generated data, which were codified in field notes. In addition to field notes, data were generated from qualitative interviews, two quantitative surveys and analysis of documents detailing strategic plans for the University of Agder beginning in 2004, and in Karlsen (2007). ${ }^{3}$

The positionality of researchers is a relevant issue in action research processes. In this case, we distinguish between two positionalities: an insider and an outsider. One of the authors, Karlsen, is an insider to the process as he has actively participated in the process in collaboration with university managers and is responsible for the course the case is based on. The other author, Larrea, participated as a lecturer for the first two weeks of the course. Her positionality is that of an outsider who helps insiders reflect on the processes that are happening. We consider that the main positionality in the chapter is that of insiders. Larrea's experience as an action researcher was mainly developed through praxis in Gipuzkoa, Basque Country (Spain) as part of a programme named the Territorial Development Laboratory, previously known as Gipuzkoa Sarean (Gipuzkoa Networked in the Basque language). The programme was 
initiated in 2009 to develop new governance modes in this region (Karlsen and Larrea 2018). Karlsen has worked as an outsider on this programme since 2009.

\section{Case}

The case study is from an ordinary course at the School of Business and Law at the University of Agder. We use the term 'case study' (Yin 2013). The case involves university actors and other regional actors. In this section, we provide a thick description (Geertz 1973) of the case. First, we address the origins of the case. Although the case focuses on developments made in Agder in 2017-2018, it is difficult to understand without framing it within processes that have underway for several years. Second, we briefly describe the third mission initiative and, finally, the design and development of the course.

\section{The Knowledge Sources and the Institutional Conditions for the Case}

There are several knowledge sources that inspired the case. One such source was a $2007 \mathrm{PhD}$ thesis on the regional role of the University by one of the authors of this chapter (Karlsen 2007). In the thesis, the concept of the co-generation of knowledge between the university and the region is discussed. At the time, this work did not have any concrete influence at the University of Agder. However, the opportunity to work with these ideas arose in the Basque Country, where attempts were being made to create the conditions for action research and, consequently, for the co-generation of knowledge between research organisations and regional actors. In 2009, the framework inspired the initial steps of the Gipuzkoa Sarean project, which later became the Territorial Development Laboratory.

The theoretical concepts developed from the work in the Basque Country and the experience of collaborating with territorial development practitioners have recently been brought back to Norway and the Agder 
region. ${ }^{4}$ The institutional conditions for conducting action research on territorial development were established with the University of Agder's 2016 strategic plan, which set out a vision for the co-creation of knowledge. One of the aims of the strategic plan was to

develop further and establish new arenas and forms of interaction and cocreation and that both University of Agder and the community must have the courage to experiment and try out new solutions and forms of cooperation. (University of Agder 2016, 6)

The aim of experimenting and testing out new forms of collaboration with external actors resonated well with the action research for territorial development developed in the Basque Country and was influential for the further development of the case. The strategic plan provided the necessary support to collaborate with regional actors. The case was initiated as a result of a request from the economic development director in Grimstad municipality for a meeting with researchers from the Department of Working Life and Innovation. This department is well known for its long tradition of collaboration with regional actors from industry and the public sector. The purpose of the meeting was to obtain support for the establishment of a strategic industrial development plan for Grimstad. The proposal to collaborate on this plan was made to Karlsen and another colleague, a professor and an expert in the regional innovation system approach. The meeting began in a traditional manner with the delivery of a report to the municipality with recommendations for action. However, during the meeting, the dialogue shifted to a discussion about engagement and co-generation of knowledge between the University of Agder and various types of actors from Grimstad, such as industry and tourism professionals, policy-makers and politicians from the municipality. Both the economic development director and the researchers thought this was a good idea. We had all had experience of reports that ended up on bookshelves collecting dust and that had little real impact. Since Karlsen had recently taken over responsibility for a 7.5 credit course (Innovation in the Public Sector) in the master's programme Innovation and Knowledge Development, the course, which had 14 
students, became the arena for experimenting with an action research process with actors in Grimstad municipality.

\section{The Third Mission Initiative-The Co-creation Lab}

When we had reached agreed with Grimstad municipality about the process, we decided to initiate collaboration with the Co-Creation Lab (Samskapingsverkstedet) at the university. At that time, the Co-Creation Lab was the official organisation for implementing the co-creation vision with regional actors. It was established as a third mission initiative, as an add-on to the teaching and research missions, at the level of the university director's office. During our collaboration with the Co-Creation Lab, we obtained information about the challenges of reaching the academic core of researchers and teachers, that is, of finding academics to collaborate with. We were also informed it was much easier to find actors in the region that were interested in collaborating with the University of Agder. We invited the leader of the Co-Creation Lab to participate in our events, and the lab used our students to promote their project during external events they organised. This gave us access to communication resources that we used to promote our course internally within the university system. The Co-Creation Lab also funded co-creation projects in the university, and, since the course was promoted as one of the pilot projects of the Co-Creation Lab, we requested funding to contract Larrea to teach at the beginning of the course. We never received the funding but decided to fund the teaching through a project we were involved with in the department at that time. The connection between us and the Co-Creation Lab can be characterised as loose and was mainly through Karlsen.

\section{Design of the Course}

The authors of this chapter designed the course together with the professor mentioned above, an associate professor from another department at the Faculty of Social Sciences and a policy-maker (the economic development director) from Grimstad. It was designed with three phases: 
teaching, co-generation and a shared reflection on the results of the cogeneration process.

The teaching phase began with a presentation of the challenge the students were to work with by the economic development director from Grimstad municipality. This was followed by a series of teaching sessions involving actors such as university managers and municipality representatives. In these sessions, traditional linear transfer of knowledge in the form of lectures was combined with co-generative methods. The cogenerative process took place over an intensive week that began with an introduction to action research for territorial development followed by group work where the students were challenged to discuss what cogeneration meant for them individually and as a group.

The second phase was the co-generation phase. The students were divided into three groups based on the challenge posed by Grimstad municipality, and each group had one supervisor from the University of Agder. The students were given the responsibility to design their engagement with actors in Grimstad. Therefore, the first part of the cogenerative phase involved students and their supervisors as it enabled them to agree on the process and the approach to co-generation that they wanted to adopt to experiment with actors. Students were given a chance to choose between different approaches. The two main approaches discussed were interviews and workshops. Due to the distinction between the roles of interviewees and interviewers, interviews focus mainly on the change process of those interviewed. Workshops allow for a more discussion of roles, including the roles of university actors. Two of the groups decided on a mixed design entailing qualitative interviews with key persons and a workshop, while the last group decided on only qualitative interviews. In total, 50 regional actors participated in the process. After the interviews and workshops, the students analysed the outcomes and discussed their analysis with the economic development director and the teachers. Students met supervisors weekly to discuss the challenges they faced during this phase. During the third phase, the outcomes of the second phase were presented to the politicians and administrators from Grimstad municipality and representatives from industry and the university. The group presentation was one part of the examination for the 
course, and the other part was an individual exam paper on the engagement process.

\section{Discussion}

In this section, we connect the discussion back to the introduction, the analytical model and the previous thick description of the case and address the theoretical implications of the case, that is, what we can learn from the case.

\section{From Liner Knowledge Transfer to Co-generation of Knowledge}

Our main aim in our role as lecturers on the course was to enable the students to learn enough from the co-generation part of the process between students and lecturers in the classroom to co-generate knowledge in collaboration with actors in Grimstad. To achieve this aim, we avoided the linear approach of telling the students what co-generation is during the intensive week. Of course, we shared our concepts and frameworks but only as part of the construction process. Co-generation is a dialogic process (Greenwood and Levin 2007) involving actors that construct the meaning of the key concepts themselves. It is a sense-making process, not a sense-giving process (Weich 1995). We worked with concepts such as action research, the co-generative model, conflict and cocreation. For this discussion, we focus on the construction of the students' concept of co-creation (samskaping), which is the vision of the University of Agder.

To begin the reflection, we used the framework on action research for territorial development (Karlsen and Larrea 2014). The main challenge was to enable students to develop an awareness (Freire 1996) of the need for a different approach than the traditional linear approach whereby university members reflect on the problems of the region, identify what they think the solutions are and write a report with recommendations for the other territorial actors. We wanted the students to assume personal 
responsibility for their own knowledge development process with the regional actors. But how could we use this approach to work with the students? Since most of them had never participated in such a process, we created a dialogical learning process in the classroom, which we combined with a series of short linear lectures as an introduction to the main action research concepts. In the classroom, the students discussed the concepts and what they meant for each student. We then challenged them to attempt to generate a shared, collective understanding of the concepts. We decided to allow them to choose their own approach after a discussion on the advantages and disadvantages of different approaches. We presented them with a scenario where they could interview the actors and write a report with recommendations for them; we called this a product perspective. But we also allowed them to decide to move away from this towards more co-generative approaches where the solutions would not be recommended by students to the actor but constructed together with the actor. We named this the process perspective. We aimed to advance from a product perspective to a process perspective slowly, but this also had to be co-generated.

\section{Constructing a Shared Understanding of Co-creation}

The Co-Creation Lab, which was responsible for the implementation of the third mission strategy, had no official definition of what co-creation (samskaping) meant or any guidelines for how co-creation should be implemented with regional actors. Therefore, there was a need to discuss the meaning of the concept since the students' were going to use it. To frame this process, students were given an opportunity to work with their own definitions of co-creation. First, the students reflected individually on the concepts discussed in the sessions. Then, they were organised into groups in which they began to share their understanding of the concepts. When they had reached a shared understanding, they presented it in a plenary session, and a discussion was initiated with the aim of arriving at a shared definition for the whole class. Reaching a shared understanding was an intense process with much negotiation about which words to choose for the definition. The co-generation process created an awareness 
in the students about the importance and the necessity of using the time available to discuss the meaning of the concepts and achieve what had to be achieved collaboratively. By reflecting on the process, they realised the challenge of moving from an individual understanding to a shared understanding in a small group to a common understanding as a class. Thus, they were able to develop an awareness of what the process of constructing solutions in collaboration with other territorial actors might be like. The following is the co-generated definition:

Co-creation is the process of working together towards a solution that is based on the exchange of ideas in a social process, where the goal is that the process should generate some form of action, change and development. (Developed by students at the University of Agder, 6 September 2017)

\section{Co-generation Is Context Specific and Complex}

The students' definition of co-creation differs from others that are not so explicit about the elements of process and change, such as the Macmillan dictionary definition:

[A] way of working together where people from different backgrounds are invited to jointly produce a product or service that will benefit all of them. (Macmillandictionary 2018)

It is reasonable to think that since the students were in a course in which action research was the dominant methodology, their definition emphasises, first, that co-creation is a social process and, second, that the process should generate some form of action, change and development. This means not only that different universities can have different approaches to regional engagement but also that, in university conceived as a loosely coupled organisation, several definitions of regional engagement will co-exist in the same environment. This does not mean that it is worthless for academics to try to develop shared definitions to take the discussion further or that regional engagement can mean anything or that it cannot be measured or evaluated. Rather, it means that approaches 
to regional engagement must deal with complexity, and complexity includes the fact that different actors in a territory will have different interpretations on what the regional challenges are and what the solutions should be.

\section{Co-generation of Knowledge Is Challenging}

There are multiple types of actors within the university who are responsible for the third mission, and we have mentioned three: administrators, academics and students. One of the lessons learnt from the case is that research and teaching can be arenas for regional development. However, not all approaches to teaching and research fit with the idea of co-generation. The transformation of research in the Basque case and the transformation of teaching in the Innovation in the Public Sector course show that integrating the first two missions into regional development is challenging. Research and teaching must integrate process perspectives with product perspectives when addressing regional development. This means taking a step away from the idea that the university should transfer knowledge and solutions to other actors and embracing co-generation.

Despite devoting the initial phase of the course to introducing students to co-generative and process-oriented methods, when students made their own decisions on how to design their approaches, one group chose exclusively to use interviews, and the other two, who decided to organise workshops, did so as a complement to interviews.

Interviews can be part of a co-generative process. However, they are typically a tool of linear approaches where researchers obtain data from practitioners and then interpret the data in non-dialogic ways. Afterwards, the interpretations are presented back to the practitioners in the form of recommendations. In our initial sessions, we attempted to encourage students to try co-generative approaches. Still, none of the groups used these approaches exclusively. We interpret that this as due to existing assumptions not only of the students but also of academics, managers and policymakers involved in the process. The linear approach is deeply rooted in the traditional understanding of the role of the university in the region 
and on how scientific or rigorous knowledge is constructed. The interpretation of the role of the responsible university in the region through cogenerative processes is based on an interpretation of responsibility as care, which includes an interpretation of the university as part of the problems of the region and part of its solutions and as caring for the shared problems because they are its own. This makes it impossible for universities to position themselves as external observers of the regional problems. They must collaborate and co-generate knowledge with regional actors.

The construction of rigorous knowledge through co-generative processes and the positionality of university actors as insiders to the region requires the initiation of an epistemological discussion on the responsible regional university.

\section{The Need for an Internal Dialogue on Regional Development Within the University}

Together with students and academics, university managers play a principal role in the development of regional responsibility. The case shows that their main challenge relates to our previous argument about the separation of the first, second and third roles of the university. Interpreting the third role as separate from the first and second roles makes it easier to manage as it means that managers do not need to initiate the process of transforming the status quo through actual teaching and research. As the case demonstrates, the eagerness to engage too much with us from the Co-Creation Lab was not present. They wanted to create something new, which initially created excitement and energy. An interpretation of the third role as one that integrates the first and second roles within it would mean that university managers would need to engage in processes to make teaching and research more sensitive to the needs of the region. However, the university is an environment in which different actors have a high level of autonomy, and management can do little to transform teaching and research without the cooperation of academics. An interpretation of the third mission that includes teaching and research is more transformative than one that considers the third mission as a separate mission. 


\section{Conclusion}

To conclude, we connect the discussion back to the introduction and the research question. In the previous thick description and the discussion of the case, we have shown how we integrated the regional development role into our teaching. The case resulted from a combination of circumstances. Through a coincidence, it was developed with Grimstad municipality. If someone from another municipality had approached us with a similar idea, the cases tried have been developed with that municipality. The conditions for such a project were present in the university, which had a new strategy with a vision for the co-creation of knowledge and the third mission initiative (the Co-Creation Lab). The conditions were also present in the academic core at the Department of Working Life and Innovation. Academics from that department had both theoretical knowledge about how to co-generate knowledge with regional actors and knowledge of how to do so in practice. They also assumed personal responsibility for engaging in regional development. The course was established with the aim of facilitating the co-generation of knowledge between students and actors in the region. We believed this could contribute to the University of Agder's vision. Thus, the case is not exclusively about the official third mission strategy nor is it only about administrators at the university taking responsibility for implementing the strategy. It is also a bottom-up initiative implemented by researchers who wanted to test knowledge generated in one context (the Basque Country) in another context (teaching in the Agder region). Abstracting from the case, we can argue that regional development is about connections in the myriad of spaces in which university actors and regional actors interact.

The official third mission strategy at the University of Agder was established as a temporary project and did not play an important or necessary role in our course. The challenge of the project was to reach into the academic core of teaching and research with the third mission initiative of co-creation. There had to be someone that was personally interested in collaborating both with the administration at university and also with regional actors. Viewed from the perspective of the academic core, it is 
much easier to choose to collaborate directly with regional actors without involving university administrators. The case shows that the existence of an official strategy developed by the university administration does not necessarily mean that the organisation is tightly coupled and that the strategy will be implemented from the top down. Such a strategy can be considered as one element of regional development that interlinks with other initiatives initiated by academics and students. A loosely coupled organisation provides flexibility for the development of initiatives like the one described. The case demonstrates that regional development cannot be solely in the form of a strategy or solely in the form of personal engagement. It must involve both institutional and personal responsibility.

As discussed in the chapter, responsibility is embodied in the practice of the individuals in universities when they act to contribute to improving the situation of the region. We define a responsible university as one in which individuals and communities who participate in any of the three missions consider the challenges of the region as constituents of their routine activities. Taking this step away from normative approaches to responsibility embodied in actions means facing complexity and participating in dialogue both inside the university (between managers, academics and students) and outside the university (with other regional actors).

If a university is a responsible university, does it need a third mission? Reflecting on the case discussed here, our argument is that a formal third mission strategy developed by the management of a university can be a useful vehicle for persons and communities in the university administration to contribute to improving the situation of the region. But, when it comes to academics and students, the first and second missions may have greater potential to make such a contribution as their daily activities, energy and innovative ideas focus on teaching and research. Consequently, we want to avoid an interpretation of regional responsibility that is exclusively connected to the third mission as this would disregard much of the practice of academics and students. If we connect responsibility to all three missions, most persons in universities would be involved in responsibility through their daily work, which would improve these processes.

Thus, the discussion of the case brings us closer to authors that argue that the third mission should be connected to teaching and research 
(Goddard et al. 2016; Karlsen et al. 2017; Uyarra 2010). However, by considering universities as loosely coupled organisations, we propose a more nuanced approach that distinguishes between different types of actors inside the university and considers that they can be involved to different extents in the three missions. While third mission strategies that are not directly integrated into teaching and research, such as sitting on boards, participating in strategic processes or organising shared events for furthering the socialisation of knowledge, can be effective vehicles for engaging universities managers in regional issues, we consider that, for academics and students, the development of responsible first and second missions has unexplored potential. The challenge is that such a transformation requires changes in teaching and research methodologies (Greenwood and Levin 2016), which is a topic to be explored in the future.

Acknowledgements We want to thank the editors for inviting us to participate in this writing process. Thanks to Patrica Canto who inspired us to work with the concept of responsible research and innovation and especially responsibility as care. Thanks to Kirsi Pulkkinen and the other editors for their valuable comments and suggestions on an earlier version of the manuscript. Any remaining errors or omissions are our own.

\section{Notes}

1. Canto, P. (2019). Research institutes as change agents in territorial development. An analytical framework on responsible research communication. (PhD thesis). Deusto University, San Sebastian.

2. By the term 'external context', we mean the environment outside the university as an organisation. The external context can be an administration region, such as the host region of a university. The same applies to the term 'external actors'. An external actor can be an actor in the host region of a university, that is, a regional actor, or an actor outside the host region. In an empirical study, the external context and external actors must be defined. 
3. Karlsen, J. (2007). The regional role of the university: A study of knowledge creation in the agora between Agder University College and regional actors in Agder. Norwegian University of Science and Technology, Trondheim.

4. For more information about the action research project in the Basque Country and concepts see, for example, Aranguren et al. (2012) and Karlsen and Larrea $(2012,2014,2016,2017,2018)$.

\section{References}

Aranguren, M. J., Karlsen, J., \& Larrea, M. (2012). Regional Collaboration The Glue That Makes Innovation Happen? In H. C. G. Johnsen \& R. Ennals (Eds.), Creating Collaborative Advantage: Innovation and Knowledge Creation in Regional Economies (pp. 113-122). Surrey: Gower.

Bardone, E., \& Lind, M. (2016). Towards a Phronetic Space for Responsible Research (and Innovation). Life Sciences, Society and Policy, 12, 5. https://doi. org/10.1186/s40504-016-0040-8.

Boyer, E. L. (1990). Scholarship Reconsidered: The Priorities of the Professoriate. Carnegie Foundation for the Advancement of Teaching.

Burget, M., Bardone, E., \& Pedaste, M. (2017). Definitions and Conceptual Dimensions of Responsible Research and Innovation: A Literature Review. Science and Engineering Ethics, 23(1), 1-19. https://doi.org/10.1007/ s11948-016-9782-1.

Charles, D., Kitagawa, F., \& Uyarra, E. (2014). Universities in Crisis? New Challenges and Strategies in Two English City-Regions. Cambridge Journal of Regions, Economy and Society, 7, 327-348.

Clark, B. R. (1998). Creating Entrepreneurial Universities: Organizational Pathways of Transformation. Oxford: IAU Press and Pergamon.

Clark, B. R. (2004). Sustaining Change in Universities: Continuities in Case Studies and Concepts. Berkshire: Society for Research into Higher Education and Open University Press.

Dunning, J. H. (2002). Regions, Globalization, and the Knowledge-Based Economy. Oxford: Oxford University Press.

Etzkowitz, H. (1983). Entrepreneurial Scientists and Entrepreneurial Universities in American Academic Science. Minerva, 21(2), 198-233.

Etzkowitz, H., \& Leydesdorff, L. (1995). The Triple Helix - UniversityIndustry-Government Relations: A Laboratory for Knowledge Based Economic Development. EASST Review, 14(1), 14-19. 
Freire, P. (1996). Pedagogy of the Oppressed. Harmondsworth: Penguin Books. Geertz, C. (1973). The Interpretation of Cultures: Selected Essays. New York: Basic Books.

Goddard, J. (2009). Re-inventing the Civic University. London: NESTA.

Goddard, J. (2011). Connecting Universities to Regional Growth: A Practical Guide. Sevilla, Spain IPTS JRC. http://ec.europa.eu/regional_policy/sources/ docgener/presenta/universities2011/universities2011_en.pdf.

Goddard, J., Hazelkorn, E., Kempton, L., \& Vallance, P. (2016). Introduction: Why the Civic University? In J. Goddard, E. Hazelkorn, L. Kempton, \& P. Vallance (Eds.), The Civic University: The Policy and Leadership Challenges (pp. 3-15). Croydon: Edwar Elgar.

Greenwood, D., \& Levin, M. (2007). Introduction to Action Research (2nd ed.). Thousand Oaks, CA: Sage.

Greenwood, D., \& Levin, M. (2016). Creating a New Public University and Reviving Democracy: Action Research in Higher Education. New York: Berghahn. Groves, C. (2009). Future Ethics: Risk, Care and Non-reciprocal Responsibility. Journal of Global Ethics, 5(1), 17-31. https://doi.org/10.1080/174496209 02765286.

Guba, E. G., \& Lincoln, Y. S. (2005). Paradigmatic Controversies, Contradictions, and Emerging Confluences. In N. K. Denzin \& Y. S. Lincoln (Eds.), The Sage Handbook of Qualitative Research (3rd ed., pp. 191-215). Thousand Oaks, London, New Delhi: Sage Publications.

Hewitt-Dundas, N. (2012). Research Intensity and Knowledge Transfer Activity in UK Universities. Research Policy, 41, 262-275.

Huggins, R., Johnston, A., \& Stride, C. (2012). Knowledge Networks and Universities: Locational and Organisational Aspects of Knowledge Transfer Interactions. Entrepreneurship and Regional Development, 24, 475-502.

Karlsen, J. (2007). The Regional Role of the University: A Study of Knowledge Creation in the Agora between Agder University College and Regional Actors in Agder Norwegian University of Science and Technology, Trondheim.

Karlsen, J., \& Larrea, M. (2012). Emergence of Shared Leadership in the Basque Country. In M. Sotarauta, I. Horlings, \& J. Liddle (Eds.), Leadership and Change in Sustainable Regional Development (pp. 212-233). London: Routledge.

Karlsen, J., \& Larrea, M. (2014). Territorial Development and Action Research: Innovation Through Dialogue. Farnham: Routledge.

Karlsen, J., \& Larrea, M. (2016). Collective Knowing. In H. Johnsen, E. S. Hauge, M. Magnussen, \& R. Ennals (Eds.), Applied Social Science Research in a Regional Knowledge System (pp. 75-89). London: Routledge. 
Karlsen, J., \& Larrea, M. (2017). Moving Context from the Background to the Forefront of Policy Learning: Reflections on a Case in Gipuzkoa, Basque Country. Environment and Planning C: Government and Policy, 35(4), 721-736. https://doi.org/10.1177/0263774X16642442.

Karlsen, J., \& Larrea, M. (2018). Regional Innovation System as a Framework for the Co-generation of Policy: An Action Research Approach. In A. Isaksen, R. Martin, \& M. Trippl (Eds.), New Avenues for Regional Innovation Systems: Theoretical Advances, Empirical Cases and Policy Lessons (pp. 257-274). New York: Springer.

Karlsen, J., Beseda, J., Šima, K., \& Zyzak, B. (2017). Outsiders or Leaders? The Role of Higher Education Institutions in the Development of Peripheral Regions. Higher Education Policy, 30(4), 463-479. https://doi.org/10.1057/ s41307-017-0065-5.

Kitagawa, F., Sánchez-Barrioluengo, M., \& Uyarra, E. (2016). Third Mission as Institutional Strategies: Between Isomorphic Forces and Heterogeneous Pathways. Science and Public Policy, 43(6), 736-750. https://doi.org/10.1093/ $\mathrm{scipol} / \mathrm{scw} 015$.

Laredo, P. (2007). Revisiting the Third Mission of Universities: Toward a Renewed Categorization of University Activities? Higher Education Policy, 20(4), 441-456.

Macmillandictionary. (2018). Co-creation. Retrieved from https://www.macmillandictionary.com/dictionary/british/co-creation.

Molas-Gallart, J., \& Castro-Martínez, E. (2007). Ambiguity and Conflict in the Development of 'Third Mission' Indicators. Research Evaluation, 16(4), 321-330. https://doi.org/10.3152/095820207X263592.

Nowotny, H., Scott, P., \& Gibbons, M. (2001). Re-thinking Science: Knowledge and the Public in an Age of Uncertainty. Cambridge: Polity Press.

OECD. (2009). OECD Regions at a Glance. Paris: The Organisation for Economic Co-operation and Development. http://www.oecd.org/document /9/0,3746,en_2649_37429_42396233_1_1_1_37429,00.html.

Perkmann, M., Tartari, V., McKelvey, M., Autio, E., Brostrom, A., D’Este, P., ... Sobrero, M. (2013). Academic Engagement and Commercialisation: A Review of the Literature on University-Industry Relations. Research Policy, 42, 423-442. https://doi.org/10.1016/j.respol.2012.09.007.

Pinheiro, R., Benneworth, P., \& Jones, G. A. (2012a). Introduction. In R. Pinheiro, P. Benneworth, \& G. A. Jones (Eds.), Universities and Regional Development: A Critical Assessment of Tensions and Contradictions (pp. 1-8). London: Routledge. 
Pinheiro, R., Benneworth, P., \& Jones, G. A. (Eds.). (2012b). Universities and Regional Development: A Critical Assessment of Tensions and Contradictions. Milton Park and New York: Routledge.

Reason, P., \& Bradbury, H. (2008). The SAGE Handbook of Action Research Participative Inquiry and Practice (2nd ed.). London: SAGE.

Rothaermel, F. T., Jiang, L., \& Agung, S. D. (2007). University Entrepreneurship:

A Taxonomy of the Literature. Industrial and Corporate Change, 16(4), 691-791. https://doi.org/10.1093/icc/dtm023.

Sánchez-Barrioluengo. (2014). Articulating the 'Three Missions' in Spanish Universities. Research Policy, 43, 1760-1773.

Schön, D. A. (1983). The Reflective Practitioner - How Professionals Think in Action. New York: Basic Books.

Spruit, S. L., Hoople, G. D., \& Rolfe, D. A. (2015). Just a Cog in the Machine? The Individual Responsibility of Researchers in Nanotechnology Is a Duty to Collectivize. Science and Engineering Ethics, 11(1), 1-17. https://doi. org/10.1007/s11948-015-9718-1.

Stilgoe, J., Owen, R., \& Macnaghten, P. (2013). Developing a Framework for Responsible Innovation. Research Policy, 42, 1568-1580.

Trippl, M., Sinozic, T., \& Smith, H. L. (2015). The Role of Universities in Regional Development: Conceptual Models and Policy Institutions in the UK, Sweden and Austria. European Planning Studies, 23(9), 1722-1740. https://doi.org/10.1080/09654313.2015.1052782.

University of Agder. (2016). Strategy 2016-2020. Kristiansand: University of Agder. Uyarra, E. (2010). Conceptualizing the Regional Roles of Universities: Implications and Contradictions. European Planning Studies, 18(8), 1227-1246. https://doi.org/10.1080/09654311003791275.

Weich, K. (1976). Educational Organizations as Loosely Coupled Systems. Administrative Science Quarterly, 21(1), 1-19.

Weich, K. (1995). Sensemaking in Organizations. Thousand Oaks, CA: Sage. Wilford, S. H. (2015). What Is Required of Requirements? A First Stage Process Towards Developing Guidelines for Responsible Research and Innovation. SIGCAS Computers and Society, 45(3), 348-355.

Wilford, S. H. (2018). First Line Steps in Requirements Identification for Guidelines Development in Responsible Research and Innovation (RRI). Systemic Practice Actionion Research, 31, 539-556. https://doi.org/10.1007/ s11213-018-9445-z.

Yin, R. K. (2013). Case Study Research: Design and Methods. Thousand Oaks, CA: Sage. 
Open Access This chapter is licensed under the terms of the Creative Commons Attribution 4.0 International License (http://creativecommons.org/licenses/ by/4.0/), which permits use, sharing, adaptation, distribution and reproduction in any medium or format, as long as you give appropriate credit to the original author(s) and the source, provide a link to the Creative Commons licence and indicate if changes were made.

The images or other third party material in this chapter are included in the chapter's Creative Commons licence, unless indicated otherwise in a credit line to the material. If material is not included in the chapter's Creative Commons licence and your intended use is not permitted by statutory regulation or exceeds the permitted use, you will need to obtain permission directly from the copyright holder.

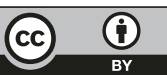

